\title{
Sustainable marketing and consumers' preferences in tourism
}

DOI 10.1515/ejthr-2016-0010

received 24 November, 2016; accepted 30 April, 2015

Abstract: Nowadays, the sustainability plays an important role in developing marketing in tourism, both from the theoretical and from the practical aspect. Sustainable marketing considers the general principles of marketing, with respect to sustainability as a new focus for a long-lasting customer relationship. Therefore, the business marketing in tourism should consider the importance of perceptions and expectations of tourists as final consumers. Regarding different marketing elements with sustainable aspect, this paper aims at investigating consumers' perceptions of foreign tourists in Republic of Macedonia. In order to provide tourist perceptions and expectations, a survey based research was conducted among 254 foreign tourists in four cities in Republic of Macedonia, concerning aspects as: tourist perceptions of marketing elements of the current tourist offering and their expectations towards sustainable tourism development. For this purpose, statistical methods have been used as: Hi2-test, Student's t-tests as well as correlation and Anova, using a specific program STAT FOR WINDOWS and STATA 11 for descriptive statistics of demographic characteristics of the sample.

The paper presents the main findings from the literature, drawing conclusions from the empirical research and providing recommendations for future academic and business research. Considering the specifics of different target segments, results from this research are presenting the need for lower pricing, increased promotional activities

\footnotetext{
*Corresponding author: Nikola Cuculeski, Faculty for Tourism and Business Logistics, University Goce Delchev, Shtip, Macedonia, Email: nikola.cuculeski@ugd.edu.mk

Ilijana Petrovska, School of Business Economics and Management, University American College Skopje, Macedonia

Vasko Cuculeski, Faculty of Tourism and Hospitality, University St. Kliment Ohridski, Bitola, Macedonia
}

using social media, providing online booking and development of ecotourism.

Keywords: Sustainability, Sustainable tourism, Sustainable marketing, Consumer behaviour, Customer Perceptions and expectations.

\section{Introduction}

With the occurrence of the marketing concept starting from the mid-20th century, the preferences and consumer behaviour are of great importance for the marketers. The application of marketing in tourism requires acceptance of basic marketing principles, including the differentiated approach for services and tourism itself. Tourism in the last 50 years develops with focus on sustainability aspects. Therefore, the concept of the tourism marketing means using the general principles of marketing, with respect to sustainability importance nowadays.

Developing a marketing concept of sustainable tourism means understanding a business in a holistic way, involving all stakeholders in a partnership on a micro, meso or macroeconomic level. As Pomering et al. (2011) recall to Belz and Peattie's (2009), there is a distinction between sustainable and sustainability marketing. The first relates to long-lasting customer relationship, and the second is more focused on the sustainable development. Conceptualizing the sustainable tourism practices, some authors stress that it should be developed upon present and future customer requirements and behaviour (Badulescu, 2014) and should analyse several aspects of consumer behaviour influence on tourism marketing (Choibamroong, 2006). According to the National Strategy for Tourism of Republic of Macedonia for 20092013 (2009), there are many weaknesses for tourism development. One of the weaknesses is the lack of research and information availability for tourism market. However from the marketing aspect, there is a need for more organised marketing activities in developing alternative forms of 
sustainable tourism according to the customer requirements and global trends.

Starting from the hypothesis that information from the final consumers could be beneficial in creating sustainable marketing for tourism development, the aim of this research is to analyse the tourist needs and wants as guidelines in developing sustainable tourism.

In the first part, the present paper reviews the relevant literature about the concept of sustainability in the area of tourism marketing, and the relevance of consumer needs and wants. The second part presents the research methodology and analysing the results in favour of understanding the consumers' requirements and needs for developing sustainable marketing in tourism. The article ends with conclusions and recommendations driven from the research.

\section{Literature review}

Using the general definition of sustainable development which implies that 'meeting the needs of the present without compromising the ability of the future generations to meet their own needs', and giving that competitive advantage is the primary goal of the marketing strategy (Martin et al, 2011) points that marketing should include sustainability goals and move companies closer to sustainable models of business. Also, tourism in the last 50 years develops with a lot of challenges from the business and customer perspectives, facing an impact from three aspects: economic, social and environmental (Badulescu et al., 2014). This aspect of sustainability is based on so-called triple bottom line framework developed by Elkington (1997). The framework encourages managers to develop and provide competitive advantage through three dimensions and therefore they should account not only the economic prosperity, but also environmental and social justice. Even though the sustainable development concepts and their implementation in tourism were growing, the sustainable practices in tourism firms have been slowly added in their management agenda (Mihalic et al, 2012).

Pomering et al. (2011) developed a sustainability tourism marketing model that embeds first the McCarthy's (1960) four P's model (product, price, place and promotion); using the Booms and Bitner's (1981) services marketing mix model with additional three P's (participants, process and physical evidence) and the Morisson's (2009) eight elements tourism marketing mix model from which used are three P's (partnership, packaging and programming). Each of these 10 elements may be cross-referenced against the triple bottom line of sustainable development to create the sustainable tourism marketing model (Pomering et al., 2011).

As Pomering et al. (2011) recall to Belz and Peattie's (2009) distinction between sustainable and sustainability marketing, the first is related to long-lasting customer relationship, and the second is more focused on the sustainable development. There are some opposite findings among authors (McDonald and Oates, 2006, Pomering et al, 2011) founding that sustainable oriented customers were weak in the usage of sustainable products.

According to Gherco and Trandafir (2014) objectives, principles and requirements of sustainable tourism development are obvious in forms of ecotourism, rural tourism, cultural and many other alternative forms of tourism. The fact that sustainable tourism in practice provides different shapes and implementation, combining business with moral and social aspects, implies some authors to doubt about the proper usage of environmental aspects and sustainable tourism in particular (Badulescu 2014, Pearce, 1986, Bartelmus, 1989). Even Berry and Ladkin (1997) consider that sustainable tourism is rather used as a marketing trick to attract new customer segments.

Another aspect of the implementation of sustainable tourism practices is given by the customer requirements and behaviour (Badulescu, 2014). For consumers and tourism companies' sustainable tourism is not able to provide the homogenous nature of the offer, taking into consideration the heterogeneous nature of the tourism offerings. According to Moisescu and Gica (2014), the permanent service quality is important for creating and maintaining customer loyalty as essential for sustainability of tourism business. Marketing in tourism is defined as a management process, based on determination of the current and potential tourist's wants and needs to develop efficient communication towards achieving customer's satisfaction and better business results.

Choibamroong (2006) is analysing several aspects of consumer behaviour influence on tourism marketing. Anon (1985) suggested that managers in tourism must identify and understand consumer needs and wants and develop marketing programs that will satisfy those mentioned items. Accordingly, the effectiveness and efficiency of marketing activities could be optimised by understanding the consumers' behaviour, and how they make their decisions for tourism. The understanding consumer behaviour could be a base for targeting selected consumers in a particular time and partial tourist products. Also, consumer behaviour as 'the actions a person takes towards purchasing and using products and services, 
including the decision-making process that precedes and determines those actions', stressing their importance for the tourism development (McColl et al., 1994, p.116).

According to Kotler (2010) contemporary market environment shows that the tourist organisations are trying to understand the influence of marketing stimulus in creating consumer decisions in their 'black box'. Marketing stimulus are the 4Ps (product, price, place and promotion) and other stimulus are the factors and the influence from the environment (economic, technological, political and cultural) (Kotler, 2010, p.182). Therefore, all of these influences on the consumer behaviour and all four factors (personal, cultural, social and psychological) for making the final consumer behaviour. Many authors mention that most often used variable for consumer behaviour, as well as base for market segmentation in tourism are demographics, socioeconomic and lifestyle variables (Tsiotsou \& Goldsmith, 2012) or going back to the Kotler's (2010) basic variables for consumer market segmentation are demographic, geographic, behavioural and psychographic. After all, it becomes clear that consumers' behaviour is never simple and is affected by many different factors, especially in the fglobalisation era. The globalisation is changing the consumer behaviour as the consumer becomes more and more sensitive when questioning and comparing products and services. In the 21st century, there is a new consumer demand that influences the business orientation and information influence their purchase behaviour (Dawkins, 2004). According to the National Strategy for Tourism of Republic of Macedonia for 2009-2013 (2009), there are many weaknesses for tourism development. One of the weaknesses is the lack of research and information availability for tourism market. However from the marketing aspect, there is a need for more organised marketing activities in developing alternative forms of sustainable tourism according to the customer requirements and global trends.

\section{Research methodology}

Starting from the hypothesis that perceptions from the final consumers could be beneficial in creating sustainable tourism marketing, the aim of this research is to analyse the tourist perceptions and expectations from marketing and sustainability aspect. Attitudes and behaviour of consumers in tourism should be an important base for business marketing and developing sustainable marketing strategies specifically for tourist organisations and other stakeholders in tourism business. For this research implemented was a questionnaire with 13 questions, divided in two groups.

The first five questions are regarding the specific demographic characteristics of the respondents. The second group questions are regarding the consumer behaviour from marketing and sustainability aspect covering opinions about pricing, promotion, tourism offerings and potentials, customers' satisfaction and their expectations for future tourism offerings from Macedonia. The questionnaire was administered in four different cities in Macedonia (Ohrid, Skopje, Bitola and Shtip) in November 2013. The sample consists of 254 respondents/foreign and domestic tourists on a voluntary basis, who visited the four specific cities. The sample is categorised upon age, gender, level of education and employment status, as most important variables influencing customer needs and wants. Due to the first five questions, the description of the sample is presented in Table 1.

It can be seen from Table 1 that most of the interviewed people are males (56\%), and 44\% are females. The average age of the interviewed is 42.33 , with a standard deviation of $\mathrm{SD} \pm 31.85$. The highest percentage is with university degree (61\%) and the highest percentage is employed (61\%).

After the analysis, the second group of questions are connected with certain answers that have mutual statistical significance and show the ratio between the tourist offer from a marketing point of view and the consumer behaviour from the aspect of their needs and preferences.

The statistical processing in the second part of the questionnaire is completed using a specific program STATFORWINDOWS. The results of the research are expressed as a percentage, and arithmetic mean with standard deviation. For the statistical processing of data, the following statistical methods have been used: Student's t-tests as well as correlation. As a statistical significance, the value of $p<0,05$ has been taken. In order to test the dependence of the proportion and the arithmetic mean, the Student's t-test has been used. To present the descriptive statistics of the questionnaire and cross-correlation, the STATA 11 program is used, by which the safety factor and accuracy of the examined variables were established.

In regards to question number 1 'Is the price the most important in your decision making for visiting specific tourist destination?', the results are presented in Table 2.

According to Table 2, it can be noticed that there is a positive correlation corel $=0.74$ from the question with positive feedback. That does not represent a perfect correlation for both answers. According to the results from the t-test, it can be seen that there is no significance in the answers on these questions, which means that the 
Table 1: Sample of 254 respondents according to the demographic characteristics

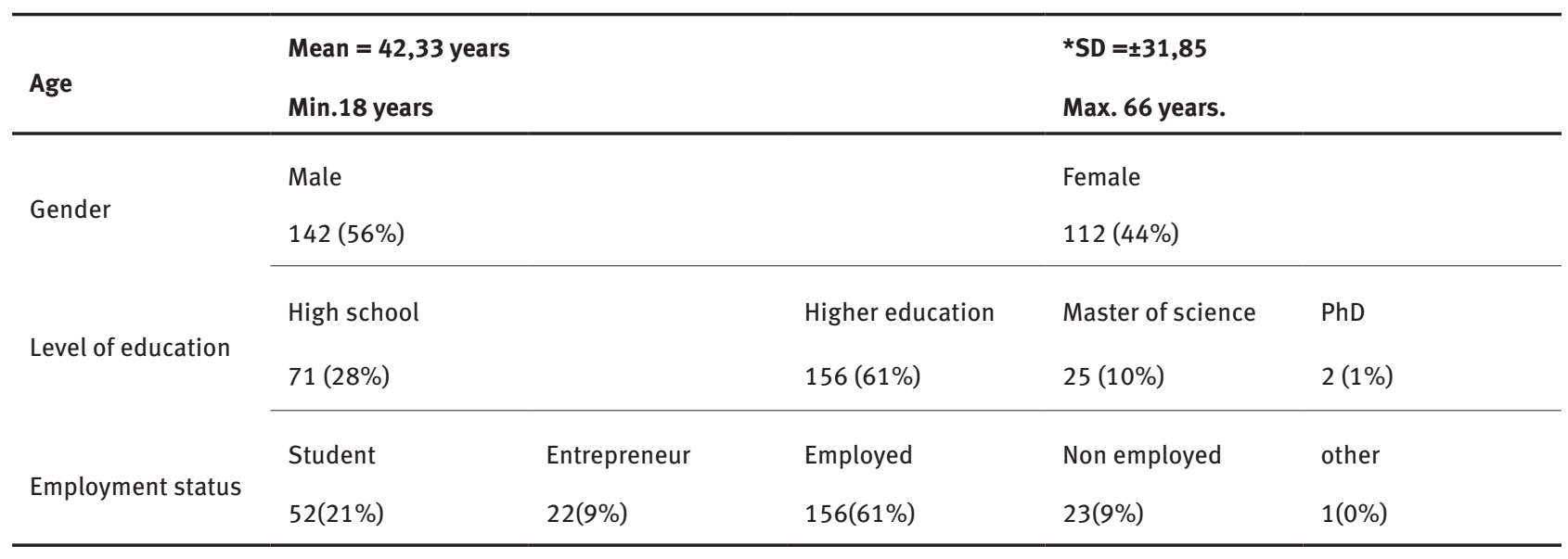

*SD-standard deviation

Source: authors' calculations

Table 2: Statistical analyses of the question 'Is the price the most important in your decision making for visiting specific tourist destination?' according to the employment status

\begin{tabular}{|c|c|c|c|c|c|c|c|}
\hline \multirow[t]{2}{*}{ Respondents } & \multirow[t]{2}{*}{ Employed } & \multirow[t]{2}{*}{ unemployed } & \multirow[t]{2}{*}{$\Sigma$} & \multicolumn{2}{|l|}{ T-test } & \multicolumn{2}{|l|}{ Corel. } \\
\hline & & & & Employed & Non-employed & Employed & Nonemployees \\
\hline \multirow[t]{2}{*}{ Yes } & 83 & 59 & 142 & 0,29 & & 0,74 & \\
\hline & & & $56 \%$ & & & & \\
\hline \multirow[t]{2}{*}{ No } & 95 & 17 & 112 & 0,5 & & 0,33 & \\
\hline & & & $44 \%$ & & & & \\
\hline \multirow[t]{2}{*}{$\Sigma$} & 178 & 76 & 254 & & & & \\
\hline & & & $100 \%$ & & & & \\
\hline
\end{tabular}

Source: authors' calculations

price does not represent a significant factor when choosing a tourist destination. By this, important information is granted to see how the tourist product should be built in the future and in which direction should the price be leaning.

When it comes to the relations for promotion and usage of the media, an analysis of question number 2 has been made: Which media do you use when choosing a tourist destination? and to question number 3: How often do you follow these media?

From the frequency of the responses in Table 3, it can be noticed that TV and Facebook have the highest frequency. From a gender point of view, the results show that there is a positive correlation in the answers in all questions, except when it comes to the radio, where a negative correlation is visible (correl $=-0.36911$ ).

The analysis of the second question shows the consumer behaviour according to the usage of different media when it comes to make a choice to visit a certain tourist destination. With the statistical analysis and Student's t-test, the data show that there is no significant difference (gender wise) in regards to the $p<0.05$ of the given values. In the analysis, the ANOVA-statistical method of analysis is used to analyse the variance for determination of the correlation between different groups of interviewed people. Also, their mean values according to university degree and gender, where $(\mathrm{p}<0.05)$. From the results, it can be concluded that there is no significant variation between the two groups ( $p<0.05)$, and it can be concluded that there are no big differences when it comes to age and employability.

On question number 4: Which is the main reason why you haven't visited a tourist destination in Macedonia?, only those who have answered positively were taken into consideration. The analysis is presented in Table 4.

The frequency of the answers received shows that the highest percentage considers that the tourist offer is not promoted well (25\%) and that there are no eco standards 
Table 3: Correlations of answers for question: Which media do you use when choosing a tourist destination? and: How often do you follow these media?

\begin{tabular}{|c|c|c|c|c|c|c|}
\hline \multicolumn{2}{|c|}{$\begin{array}{l}\text { Which media do you use when } \\
\text { choosing a tourist destination? }\end{array}$} & \multirow{2}{*}{$\begin{array}{l}\text { Daily } \\
77\end{array}$} & \multirow{2}{*}{$\begin{array}{l}\begin{array}{l}\text { 3-5 times a } \\
\text { week }\end{array} \\
17\end{array}$} & \multirow{2}{*}{$\begin{array}{l}\begin{array}{l}1-3 \text { times a } \\
\text { week }\end{array} \\
21\end{array}$} & \multirow{2}{*}{$\begin{array}{l}\text { Never } \\
6\end{array}$} & \multirow{3}{*}{$\begin{array}{l}\text { Correlation } \\
0,86137\end{array}$} \\
\hline TV & Male & & & & & \\
\hline & Female & 87 & 23 & 18 & 5 & \\
\hline \multirow{2}{*}{ Radio } & Male & 47 & 26 & 34 & 17 & \multirow{2}{*}{$-0,36911$} \\
\hline & Female & 15 & 19 & 42 & 54 & \\
\hline \multirow{2}{*}{$\begin{array}{l}\text { Newspapers and } \\
\text { magazines }\end{array}$} & Male & 31 & 19 & 41 & 23 & \multirow{2}{*}{0,997476} \\
\hline & Female & 35 & 25 & 49 & 31 & \\
\hline \multirow[t]{2}{*}{ Facebook } & Male & 80 & 14 & 8 & 27 & \multirow[t]{2}{*}{0,991909} \\
\hline & Female & 85 & 13 & 10 & 17 & \\
\hline \multirow[t]{2}{*}{ Twitter } & Male & 17 & 11 & 17 & 76 & \multirow[t]{2}{*}{0,998906} \\
\hline & Female & 2 & 2 & 7 & 122 & \\
\hline
\end{tabular}

Source: authors' calculations

Table 4: Statistical analyses of the question: Which is the main reason why you haven't visited a tourist destination in Macedonia?

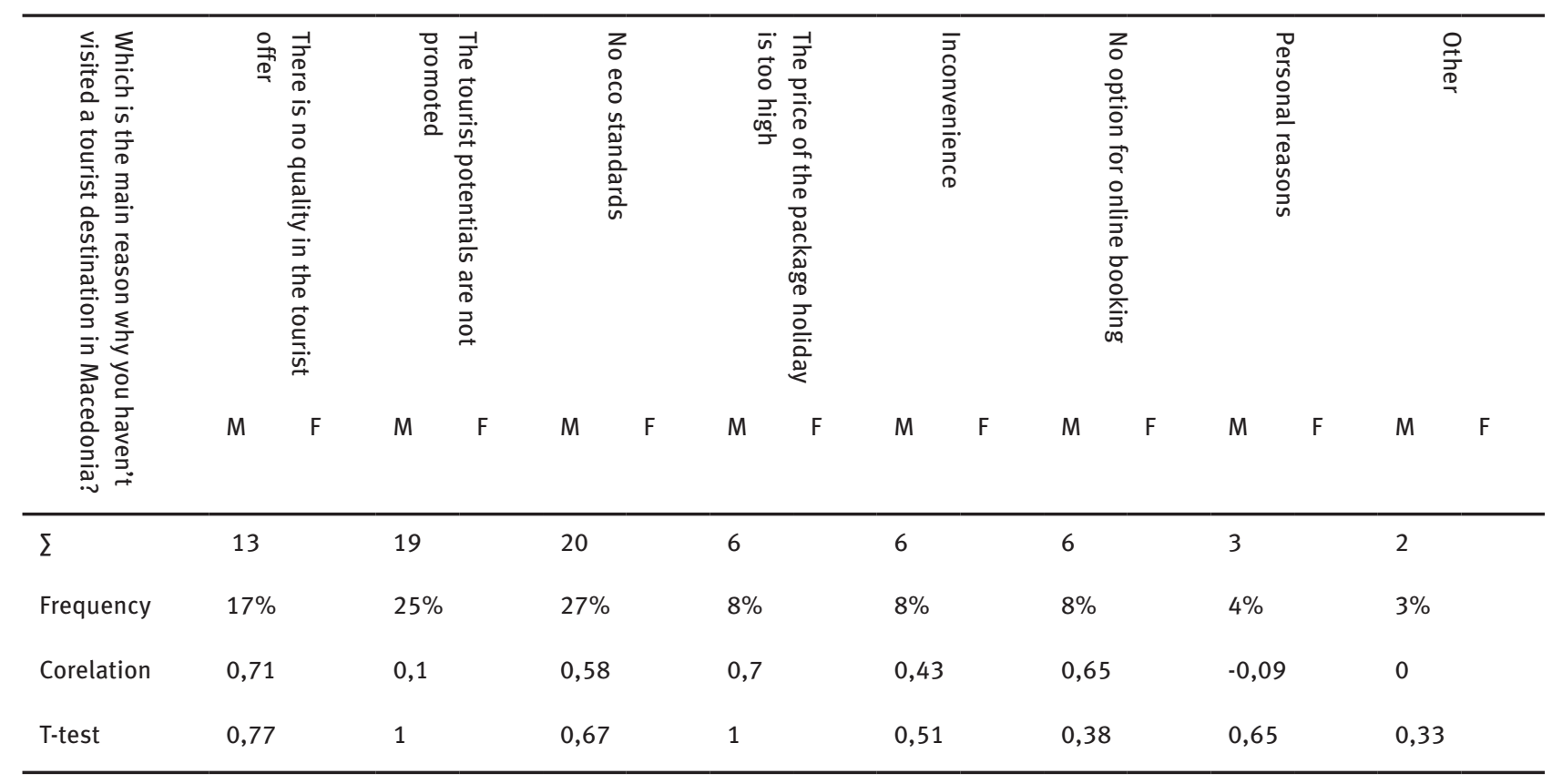

Source: authors' calculations

(27\%). In regards to the correlation, the highest value can be noticed in the first answer: There is no quality in the tourist offer (corel. $=0.71$ ), whereas a negative value of correlation can be seen in the answers by Personal reasons (corel.=-0.09). According to $\mathrm{p}<0.05$, it can be said that there is no significance. From the analysis, it can be concluded that promotion and eco-tourism are extremely important when it comes to the creation of tourist offer in Macedonia.

To this conclusion, the analysis of can be applied in different levels from macro, mezzoz the last question can be added on: In your opinion, what can be done to improve the tourist offer in Macedonia? The following table shows the results to this question. 
From the analysis of the data in Table 5, it can be noticed that there are high values in some of the answers. In particular, those which include create a more attractive tourist product (73\%) and Development and active offer of eco-tourism and other forms of alternative tourism (67\%). There is no significant difference when it comes to $\mathrm{p}<0.05$. The correlation of the answer development and active offer of eco-tourism and other forms of alternative tourism to this question is high $(0.93 \%)$. This shows that the consumers are aware for the need of new forms of tourist offer, as an essential part of the development of sustainable tourism.

\section{Conclusions}

From theoretical and practical point of view, it is of great importance to define the consumer behaviour in tourism, which is also important for the systematic guidance of the marketing activities according to the need, wants and preferences of the consumers. Starting from the hypothesis that information from the final consumers could be beneficial in creating sustainable marketing for tourism development, using the analyses of the tourist perceptions and expectations from marketing and sustainability aspect, these results present the need for the development of the marketing elements as an important factor for sustainable marketing in tourism. In regards to the tourist offer, these results represent the need of upgrading of the quality of the tourist offer and creation of new forms towards sustainable tourism development.

The research gives clear guidance that the price is not the basic marketing tool for the customers and that they don't base their decision solely on the price of the tourist product. The research shows that the marketing efforts should be narrowed towards the target group of 26-35 years of age that has a university degree and which is employed. To their decision to travel, significant influence has the social media and the television. That means that the future tourist offer should be towards that target group and all the efforts should be made in order to create a complete tourist offer.

In order to make upgrades and improvements to the tourist offer, there is a need of promotion and focus towards eco-tourism. This can be seen from the results of the research. The data also show that the price and availability of the tourist product, as well as the on-line booking possibilities are significant factors when it comes to improvements in the tourism offer.

The results represent a solid basis for the creation of recommendation and development of sustainable marketing of tourism and can be applied at different levels from macro, mezzo and micro. In order to have a successful sustainable development of tourism further research in different areas needs to be done, especially when it comes to the social and psychological factors of consumer behaviour, research of alternative forms of tourism, as

Table 5: Statistical analyses of the question: In your opinion, what can be done to improve the tourist offer in Macedonia?

\begin{tabular}{|c|c|c|c|c|c|c|}
\hline & $\Sigma$ & & Frequency & Correlations & T-test & \\
\hline & M & $\mathrm{F}$ & & M & M & $\mathrm{F}$ \\
\hline & 254 & & & & & \\
\hline \multirow{2}{*}{ Create a more attractive tourist product } & 185 & & \multirow{2}{*}{$73 \%$} & \multirow{2}{*}{0,83} & \multirow{2}{*}{0,85} & \\
\hline & 97 & 88 & & & & \\
\hline \multirow{2}{*}{$\begin{array}{l}\text { The price of the tourist product should be } \\
\text { decreased }\end{array}$} & 92 & & \multirow{2}{*}{$36 \%$} & \multirow{2}{*}{0,70} & \multirow{2}{*}{0,9} & \\
\hline & 47 & 45 & & & & \\
\hline \multirow{2}{*}{$\begin{array}{l}\text { To improve the quality of the promotional } \\
\text { material }\end{array}$} & 71 & & \multirow{2}{*}{$28 \%$} & \multirow{2}{*}{0,17} & \multirow{2}{*}{0,82} & \\
\hline & 37 & 34 & & & & \\
\hline \multirow{2}{*}{ To make the tourist product more available } & 93 & & \multirow{2}{*}{$37 \%$} & \multirow{2}{*}{0,66} & \multirow{2}{*}{0,90} & \\
\hline & 44 & 49 & & & & \\
\hline \multirow{2}{*}{$\begin{array}{l}\text { Development and active offer of eco-tourism and } \\
\text { other forms of alternative tourism }\end{array}$} & 171 & & \multirow{2}{*}{$67 \%$} & \multirow{2}{*}{0,93} & \multirow{2}{*}{0,92} & \\
\hline & 89 & 82 & & & & \\
\hline \multirow{2}{*}{ Other } & 11 & & \multirow{2}{*}{$4 \%$} & \multirow{2}{*}{0} & \multirow{2}{*}{0,33} & \\
\hline & 11 & 0 & & & & \\
\hline
\end{tabular}

Source: authors' calculations 
well as research of the new elements of the contemporary and sustainable marketing mix.

\section{References}

[1] Anon, (1985). AMA Board Approves New Marketing Definition. Marketing Educator, Spring, p. 1.

[2] Badulescu, A., Badulescu, D., Bac, D. \& Sipos-Gug, S. (2014). Attitudes and intentions of Business Master Students towards Sustainable tourism and entrepreneurship. Amfiteatru Economic. Vol. XVI. Special No.8. November 2014, pp. 1110-1124

[3] Bartelmus, P. (1989). Environment and Development. London: Allen and Unwin.

[4] Belz and Peattie's (2009). Sustainability marketing, a global perspective. Chichester: Wiley

[5] Berry, S. and Ladkin, A. (1997). Sustainable Tourism: A Regional Perspective. Tourism Management. 18(7), pp.433-440

[6] Booms, B.H. \& Bitner, M.J. (1981). Marketing strategies and organizational structures for service firms. In J.H. Donnelly \& W.R. George (Eds.), Marketing of services (pp. 47-51). Chicago, IL: American Marketing Association.

[7] Choibamroong, T. (2006). Knowledge of tourism behaviour: A key success factor for managers in tourism business. International Journal of Tourism Research, pp. 1-8

[8] Crompton J.L. (1997). A system model of the tourist's destination selection process. Unpublished doctoral dissertation. Texas A\&M University, 1977, pp. 181-193

[9] Dawkins, J. (2004). Corporate responsibility: The communication challenge. Journal of Communication Management, 9(2), pp.108-119

[10] Elkington, J. (1997). Cannibals with forks. Oxford: Capstone.

[11] Gherco, A. V. \& Trandafir, A. (2014). Tourism development in the terms of sustainable development in Romanie. Economics, Management \& Financial Markets, 9(1), pp. 207-212

[12] Kotler, P., Bowen, J.T., Makens, J.C. (2006). Marketing for hospitality and tourism. Upper Saddle River, NJ: Pearson education

[13] Martin D \& Schouten J. (2011). Sustainable marketing. Prentice Hall; 1 edition

[14] McCarthy, E.J. (1960). Basic marketing: A managerial approach. Homewood, IL: Irwin.

[15] McColl, K.JR., Kiel, G.G., Lusch, R.F., \& Lusch, V.N. (1994). Marketing: Concepts and Strategies, Acumen Overseas Pte. Ltd, Singapore

[16] McDonald, S. \& Oates, C.J. (2006). Sustainability: Consumer perceptions and marketing strategies. Business Strategy and the Environment, 15(2), pp. 157-170

[17] Mihalic, T., Zabkar, V. \& Cvelbar, L. K. (2012). A hotel sustainability business model: evidence from Slovenia. Journal of Sustainable Tourism, 20(5), pp. 701-719. doi: 10.1080/09669582.2011.632092
[18] Moisescu, O. I. \& Gică, O.A. (2014) Amfiteatru Economic. 16, No. Special 8/2014

[19] Morrison, A. (2009). Hospitality and travel marketing (4th ed.). Albany: Delmar Cengage Learning

[20] National Strategy for Tourism of Republic of Macedonia for 2009-2013 (2009) Government of Republic of Macedonia

[21] Pearce, D., (1986). Blueprint for a Green Economy. London: Kogan Page

[22] Pomering, A., Noble, G. \& Johnson, L.W. (2011). Conceptualising a contemporary marketing mix for sustainable tourism. Journal of Sustainable Tourism, 19(8), pp. 953-969. doi: 10.1080/09669582.2011584625

[23] Tsiotsou, R. H. \& Goldsmith, R. E. (2012). Strategic Marketing in Tourism Services.

Nikola Cuculeski, $\mathrm{PhD}$, is a tourism professional with more than 5 years of experience in the field of tourism, management in tourism, marketing in tourism as well as strategic marketing and consumer behaviour in tourism. He is a young but very ambitious professional that already has a background in lecturing and consultancy in management and tourism as well. At the moment he is involved as a titled Associate Professor at the Faculty of Tourism and Business Logistics in Shtip and Skopje.

Ilijana Petrovska, $\mathrm{PhD}$ is an Associate professor lecturing several courses in the field of Marketing at graduate and undergraduate level at University American College Skopje, Macedonia and visiting professor at Rome Business School, Italy. She is a consultant at EBRD BAS Macedonia implementing Market research projects and providing Executive education in Marketing. Her research areas are mainly in Integrated marketing communications, Marketing in Banking, Measuring Marketing, Social media, Branding, Marketing for Entrepreneurship and Quality education. Her previous professional experience as a Marketing Manager in the biggest bank in Macedonia supports all her research and academic activities. Since October 2013 is promoted to a Vice Dean for Education at UACS School of Business Economics and Management and continues to lead the Marketing Department. In parallel is volunteering as a President of the Association for Better Education.

Vasko Cuculeski, PhD is a Professor at the Faculty of Tourism and Hospitality in Ohrid. His main scope of interest is the gastronomy and the marketing of gastronomy. He has more than 35 years of experience in his field. 